\title{
KLASIFIKASI PENYAKIT PARU BERDASARKAN CITRA RONTGEN DENGAN METODA SEGMENTASI SOBEL
}

\author{
Reni Rahmadewi*, Rahmadi Kurnia \\ Jurusan Teknik Elektro, Fakultas Teknik, Univertsitas Andalas \\ *Corresponding author, e-mail : reni.rahmadewi@gmail.com
}

\begin{abstract}
Abstrak-Penyakit paru merupakan salah satu penyakit yang umum dijumpai di masyarakat. Seringkali terjadi keterlambatan dalam penanganan terhadap penyakit paru ini. Keterlambatan ini biasanya disebabkan oleh ketidaktahuan masyarakat dalam penanganan yang tepat dan kurangnya informasi yang jelas tentang penyakit paru. Salah satu cara untuk mendeteksi penyakit paru adalah dengan membaca gambar rontgen yang benar dan biasanya dilakukan oleh pakar yang ahli terhadap hasil rontgen tersebut. Akan tetapi untuk mendapatkan hasil diagnosa ini tergantung pada jadwal praktek dari pakar dan membutuhkan waktu yang lama. Untuk memudahkan kesulitan masyarakat ini, maka pada penelitian ini dibangun aplikasi yang bisa menganalisa gambar rontgen berdasarkan pengolahan citra. Data yang diolah ada 41 (empat puluh satu) citra rontgen dengan melakukan segmentasi terhadap region paru. Kemudian region paru ini dilakukan deteksi tepi berbasis operator sobel. Hasil pengujian didapatkan dari perbandingan piksel antara hasil deteksi tepi terhadap region paru, yang mengklasifikasikan 6 (enam) jenis penyakit paru dengan interval persentase untuk penyakit bronkitis sebesar $1,43 \%-1,59 \%$, penyakit pleuritis $1,43 \%-1,59 \%$, penyakit pneumonia $2,00 \%-2,50 \%$, penyakit TBC $2,86 \%$ - 3,79\%, penyakit emfisema $4,16 \%-4,76 \%$ dan penyakit kanker paru $76,72 \%-94,85 \%$.
\end{abstract}

Kata Kunci : Penyakit paru, citra rontgen, segmentasi, operator sobel.

\begin{abstract}
Lung disease is one of the diseases that are prevalent in society. Often there is a delay in the treatment of this lung disease. These delays are often caused by ignorance of the community in the proper handling and lack of clear information about lung disease. One way to detect lung disease is by reading the $\mathrm{X}$-ray images are correct and are usually carried out by experts who are experts on the X-ray results. But to get the diagnosis depends on the schedule of expert practice and takes a long time. To ease the difficulties of this society, so in this study built applications that can analyze X-ray images based on image processing. The data is processed there are 41 (forty-one) X-ray image of the segmentation of the lung region. Then the lung region performed edge detection based on Sobel operator. The test results obtained from the comparison of pixels between the results of edge detection on the lung region, which classifies six (6) types of lung disease with a percentage interval for bronchitis of $1.43 \%-1.59 \%$, pleurisy $1.43 \%-1.59 \%$, pneumonia $2.00 \%-2.50 \%$, tuberculosis $2.86 \%-3.79 \%$, emphysema $4.16 \%-4.76 \%$ and lung cancer $76.72 \%-94.85 \%$.
\end{abstract}

Keyword: lung disease, X-ray image, segmentation, Sobel Operator

\section{Copyright (C) 2016 JNTE. All rights reserved}

\section{PENDAhUluan}

Paru-paru merupakan salah satu organ pada sistem pernapasan yang berfungsi sebagai tempat bertukarnya oksigen dengan karbondioksida di dalam darah. Permasalahan yang sering terjadi adalah kualitas udara yang telah tercemar, sehingga udara yang dihirup banyak mengandung bibit penyakit yang akan menyerang paru-paru. Penyakit paru-paru merupakan penyakit yang berdampak serius terhadap sistem pernapasan pada manusia yang dapat berakibat fatal apabila tidak segera ditangani dengan serius. Gangguan paru-paru ini menyebabkan penderita sulit bernafas, sulit beraktivitas, kekurangan oksigen bahkan apabila tidak cepat terdeteksi dapat menyebabkan kematian[1]. Ada beberapa penyakit paru secara umum dijumpai yaitu tuberkulosis, bronkitis, pneumonia, kanker paru, emfisema dan pleuritis.

Untuk mendeteksi penyakit/gangguan paruparu pada umumnya dilakukan secara klinis (gejala fisik oleh dokter). Selain dari pemeriksaan secara klinis, penyakit paru juga dapat didiagnosa melalui foto rontgen, CT scan dan MRI, hanya saja untuk dua cara yang 
terakhir membutuhkan biaya yang mahal[2]. Permasalahan lainnya adalah pengetahuan masyarakat yang minim dalam membaca hasil rontgen, sehingga masih dibutuhkan tenaga ahli seperti dokter atau tenaga medis lain untuk membacanya. Selain itu masyarakat yang tinggalnya jauh dari kota, butuh waktu yang lama untuk mendapatkan hasil diagnosa gambar rontgen, dikarenakan menunggu jadwal praktek dokter ahli terlebih dahulu.

Pengolahan citra digital sekarang berkembang cepat, dan dapat digunakan di dalam dunia medis seperti menganalisis gambar rontgen, sehingga dapat memecahkan permasalahan analisis citra untuk mengidentifikasi penyakit paru-paru. Hasil citra rontgen sering nampak kabur, kurang kontras, dan sebagainya, sehingga satu citra yang diamati oleh beberapa pengamat dapat menghasilkan pembacaan yang berbeda-beda. Buruknya hasil visualisasi citra rontgen disebabkan karena sedikitnya perbedaan redaman sinar-X antara jaringan kelenjar normal dan jaringan kelenjar yang terkena penyakit paru-paru. Untuk mengatasi masalah tersebut digunakan pengolahan citra untuk meningkatkan dan memperbaiki mutu citra, seperti Achmad Hidayatno, dkk[3] dengan menganalisis deteksi tepi pada citra berdasarkan perbaikan kualitas citra. Kemudian Danny Ibrahim, dkk[4] melakukan pengaturan kecerahan dan kontras citra berdasarkan teknik pemodelan histogram, sehingga dapat dibedakan dengan jelas antara paru-paru sehat dengan paru-paru yang bermasalah.

Pada penelitian ini dibuat sebuah simulasi dalam klasifikasi penyakit paru berdasarkan citra rontgen dengan metoda segmentasi sobel.

\section{TINJAUAN PUSTAKA}

\subsection{Citra Rontgen}

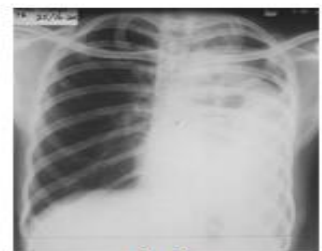

(a)

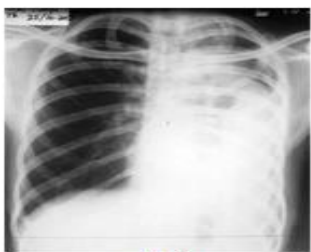

(b)

Gambar 1. (a) Citra rontgen, (b) Citra rontgen setelah diperbaiki
Salah satu pemeriksaan penyakit paru adalah dengan pemeriksaan radiologi yang dikenal dengan sinar- $\mathrm{X}$ atau foto rontgen. Foto rontgen ini paling sering digunakan, karena akan memberikan hasil yang berbeda secara langsung. Sampel citra rontgen dan sampel citra rontgen yang telah diperbaiki dapat dilihat pada Gambar 1.

\subsection{Histogram}

Histogram citra adalah alat bantu yang sangat penting dalam proses pengolahan citra digital. Histogram citra ini menampilkan sebaran nilai-nilai intensitas piksel dari suatu citra atau menunjukkan bagian-bagian tertentu dari citra (misalnya bagian latar belakang dan objek utama citra). Histogram bermanfaat untuk hal-hal berikut[5] yaitu:

1. Sebagai indikasi visual untuk menentukan skala keabuan yang tepat sehingga diperoleh kualitas citra yang diinginkan.

2. Untuk pemilihan ambang batas (threshold).

\subsection{Perbaikan Kualitas Citra}

Perbaikan kualitas citra (image enhancement) merupakan salah satu proses awal dalam melakukan pengolahan citra (image preprocessing). Perbaikan kualitas citra diperlukan karena citra yang diuji biasanya mempunyai kualitas yang kurang bagus, misalnya citra mengalami derau (noise) pada saat pengiriman melalui saluran transmisi, citra terlalu terang/gelap, citra kurang tajam, kabur, dan lain-lain.

\subsection{Segmentasi}

Segmentasi merupakan proses pemisahan wilayah (region) tertentu pada citra, dimana region tersebut memiliki homogenitas diantaranya tekstur, intensitas dan warna. Segmentasi citra bertujuan untuk memisahkan region objek dengan latar belakang, agar objek di dalam citra mudah dianalisis dan mengenali objek gambar[6].

Thresholding merupakan teknik utama dalam analisa similaritas. Dengan menentukan ambang batas yang tepat untuk setiap pengolahan citra yang dapat menghasilkan suatu citra dengan level biner.

Adapun langkah-langkah penentuan threshold dengan metoda iterasi[7] sebagai berikut : 
1. Tentukan nilai threshold awal $\mathrm{T}_{0}$

2. Citra di bagi dua daerah dengan menggunakan nilai awal threshold pada langkah 1. (R1 dan R2).

3. Hitung nilai rata-rata intensitas pada tiap daerahnya ( $\mu 1$ dan $\mu 2)$.

4. Hitung nilai threshold baru dari penjumlahan nilai rata-rata intensitas yang di bagi 2 . [ $\mathrm{T}=$ $(\mu 1+\mu 2) / 2]$.

5. Ulangi langkah 2 hingga 4 sampai nilai ratarata intensitas ( $\mu 1$ dan $\mu 2)$ tidak berubah.

Metode segmentasi amplitudo (Amplitudo

Segmentation Methods) ini paling banyak digunakan berdasarkan pada perbedaan tingkat luminansi (luminance level) maupun level warna antara objek dengan latar belakangnya pada sebuah citra. Metode ini disebut juga dengan metode thresholding berbasiskan histogram.

\subsection{Deteksi Tepi}

Deteksi tepi (Edge Detection) pada suatu citra adalah suatu proses yang menghasilkan tepi-tepi dari objek citra, tujuannya adalah untuk menandai bagian yang menjadi detail citra.

Operator sobel melakukan perhitungan secara 2D terhadap suatu ruang di dalam sebuah gambar dengan harapan nantinya akan tampak daerah-daerah bernilai tinggi pada gambar tersebut yang merupakan deteksi tepi dari suatu gambaran.

Operator ini biasanya digunakan untuk mencari gradien dari masing-masing piksel gambar input yang telah di grayscale sebelumnya. Secara teori, diperlukan matrik setidaknya berukuran $3 \times 3$ sebagai kernelnya. Operator sobel menunjukkan kernel $3 \times 3$ seperti Gambar 2 berikut :

\begin{tabular}{|l|l|l|}
\hline-1 & 0 & +1 \\
\hline-2 & 0 & +2 \\
\hline-1 & 0 & +1 \\
\hline
\end{tabular}

Gx

\begin{tabular}{|c|c|c|}
\hline+1 & +2 & +1 \\
\hline 0 & 0 & 0 \\
\hline-1 & -2 & -1 \\
\hline
\end{tabular}

Gy
Gambar 2. Kernel 3x3 operator sobel

\section{METODOLOGI}

Citra rontgen yang digunakan ada 41 citra rontgen, yang diambil dari beberapa sampel di
RSUD Pariaman, dan beberapa dari Internet. Citra yang diinputkan menggunakan format jpeg (*jpg).

\subsection{Perancangan Penelitian}

Blok diagram penelitian ini dapat dilihat pada Gambar 3 berikut:

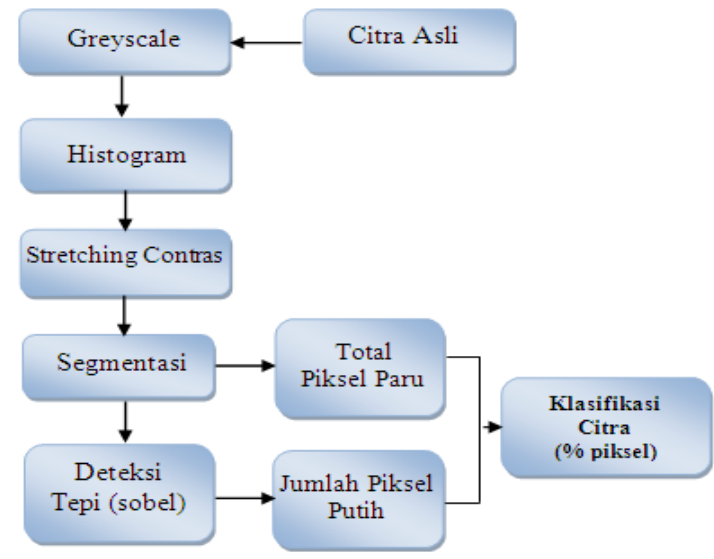

Gambar 3. Blok diagram penelitian

Pada rancangan ini dilakukan beberapa langkah sebagai berikut:

3.1.1. Mengubah citra asli menjadi citra grayscale.

Citra yang diinputkan adalah citra digital, berupa gambar rontgen dengan format jpeg (*jpg), kemudian citra tersebut dirubah menjadi grayscale, sehingga tidak ada lagi citra warna tetapi hanya ada derajat keabuan. Untuk konversi citra warna menjadi citra grayscale ini menggunakan persamaan berikut:

$$
\text { Grayscale }=\frac{R+G+B}{3}
$$

Setiap piksel warna diambil dari komponen Red, Green, dan Blue, dan menggunakan persamaan di atas sehingga didapat komponen greyscale dari piksel tersebut. Hasil citra grayscale tersimpan pada variabel tertentu yaitu disimpan dalam variable TmpByte.

3.1.2. Membuat histogram citra rontgen grayscale.

Setelah memperoleh citra grayscale, langkah selanjutnya adalah membuat histogram citra grayscale. Dengan adanya histogram nantinya akan terlihat kualitas citra terlalu terang atau terlalu gelap. Inisialisasi variable 
HistogramTmp untuk menampung hasil histogram yang dibuat, kemudian menguji derajat keabuan dari tiap piksel, dikelompokkan berdasarkan derajat keabuan piksel dan dihitung jumlah piksel yang tergolong dari derajat keabuan tersebut.

\subsubsection{Memperbaiki kualitas citra rontgen paru}

Langkah selanjutnya adalah memperbaiki kualitas citra rontgen paru. Perbaikan kualitas citra yang dipakai adalah stretching contras dan modifikasi histogram.

Stretching contrast memastikan bahwa citra hasil perbaikan memiliki penyebaran nilai kontras yang lebar dan tidak lagi terlalu gelap ataupun terlalu terang. Kemudian memodifikasi histogram yang dilakukan dengan melakukan pelembutan histogram yaitu histogram difilter dengan low pass filter sehingga amplitudo histogram bisa lebih sedikit riak pada amplitudonya yang bertujuan dalam proses segmentasi.

\subsubsection{Melakukan segmentasi pada citra rontgen paru}

Setelah dilakukan perbaikan kualitas citra, langkah selanjutnya adalah dilakukan proses segmentasi. Segmentasi pada penelitian ini menggunakan metode base on thresholding yaitu multilevel luminance thresholding dengan perhitungan iterasi. Metode iterasi ini disebut juga dengan metode amplitudo karena menggunakan amplitudo histogram dengan pencarian titik-titik threshold. Metode multilevel luminance thresholding dengan langkah-langkah sebagai berikut:

1. Simpan nilai batas kiri (Lbound) dan batas kanan (Ubound) histogram (untuk pertama kali Lbound $=0$ dan Ubound $=255$ ).

2. Uji status modalitas, jika bimodal maka jalankan bilevel luminance thresholding sehingga mendapatkan threshold (T).

3. Gunakan nilai T sebagai Ubound dan Lbound $=0$.

4. Ulangi langkah 2 dan 3 hingga status modalitas tidak bimodal dan simpan $\mathrm{T}$ menjadi $\mathrm{Th}_{1}$

5. Ubah nilai Lbound dengan nilai $\mathrm{TL}$ dan Ubound $=255$.

6. Lakukan langkah 2 dan simpan nilai $\mathrm{T}$ menjadi $\mathrm{Th}_{2}$
Setelah titik-titik threshold (Th1 dan Th2) ditemukan, kemudian dilakukan proses segmentasi untuk menentukan region paru dari citra rontgen, yaitu dengan ketentuan:

$$
\mathrm{F}(\text { indeks })=\left\{\begin{array}{l}
255, \text { apabila berada antara } \mathrm{Th} 1 \mathrm{dan} \mathrm{Th} 2 \\
0, \text { untuk yang lainnya }
\end{array}\right.
$$

3.1.5. Melakukan deteksi tepi pada citra rontgen paru

Deteksi Tepi yang digunakan adalah operator sobel, yaitu menggunakan ukuran matrik 3x3. Operator ini dipilih karena merupakan operator sederhana yang memungkinkan dilakukan pada perangkat dengan prosesor minim seperti pada smart phone. Setelah hasil region paru didapatkan, kemudian langkah selanjutnya dilakukan proses deteksi tepi untuk memperjelas perbedaan rentang greyscale satu piksel terhadap piksel tetangganya.

\subsection{Klasifikasi Citra Rontgen}

Hasil persentase citra rontgen paru dapat dilihat pada Tabel 1, dimana hasil persentase didapatkan dari perbandingan jumlah piksel putih (deteksi tepi) dengan total piksel paru (segmentasi). Klasifikasi penyakit paru dari tiaptiap penyakit paru dapat dilihat pada Gambar 4.

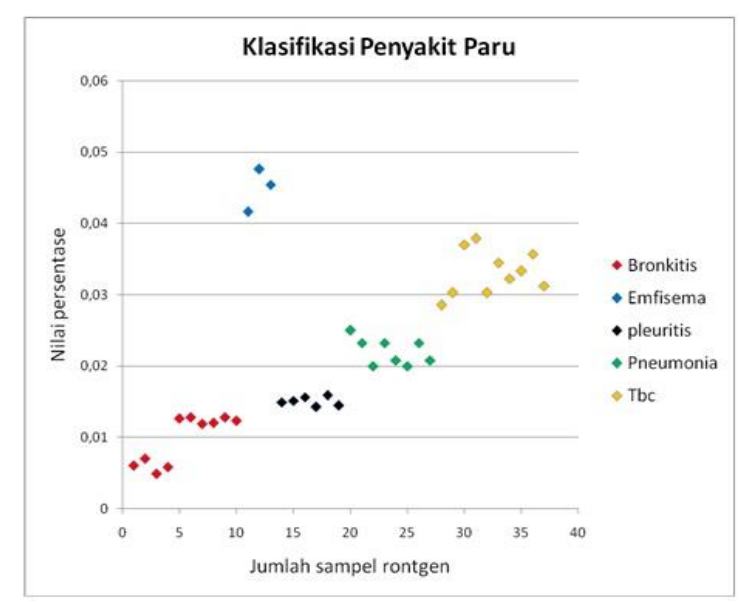

Gambar 4. Klasifikasi Penyakit Paru

Nilai persentase untuk 4 sampel penyakit kanker paru dapat dilihat pada Gambar 5 dan hasil persentase interval dari tiap-tiap jenis penyakit paru dapat di lihat pada Tabel 1 . 


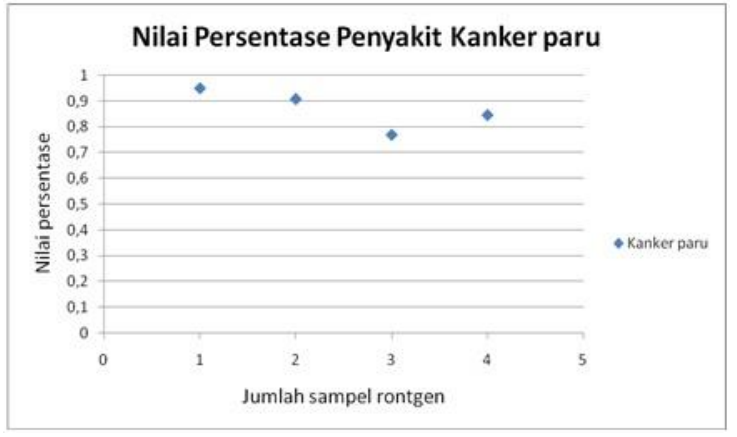

Gambar 5. Nilai persentase untuk 4 sampel citra rontgen penyakit kanker paru

Tabel 1. Hasil interval persentase dari tiap-tiap penyakit paru

\begin{tabular}{|c|c|c|c|c|}
\hline No & Min & Max & Range & Penyakit \\
\hline 1 & $0,49 \%$ & $1.28 \%$ & $0.0049-0.0128$ & Bronkitis \\
\hline 2 & $1.43 \%$ & $1.59 \%$ & $0.0143-0.0159$ & Pleuritis \\
\hline 3 & $2.00 \%$ & $2.50 \%$ & $0.02-0.025$ & Pneumonia \\
\hline 4 & $2.86 \%$ & $3.79 \%$ & $0.0286-0.037$ & TBC \\
\hline 5 & $4.16 \%$ & $4.76 \%$ & $0.0417-0.0476$ & Emfisema \\
\hline 6 & $76.72 \%$ & $94.85 \%$ & $0.7672-0.9485$ & Kanker paru \\
\hline
\end{tabular}

\section{HASIL DAN ANALISA PENGUJIAN}

\subsection{Sampel citra rontgen TBC}

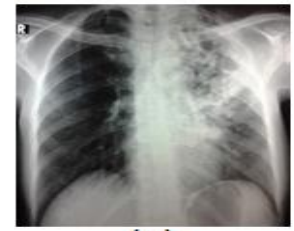

(a)

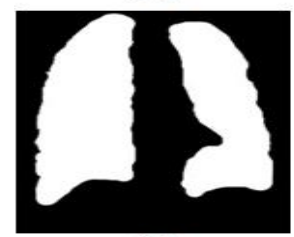

(c)

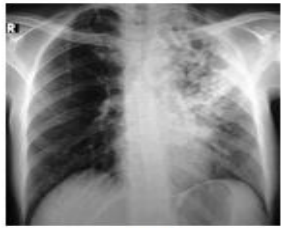

(b)

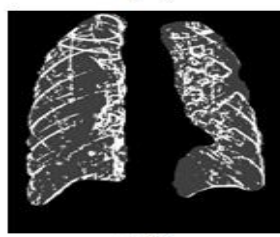

(d)
Gambar 6. (a) Citra asli, (b) Citra setelah diperbaiki, (c) Citra hasil segmentasi (d) Citra hasil deteksi tepi

Sampel citra rontgen yang diinputkan dapat dilihat pada gambar 6(a), kemudian citra asli diperbaiki pada gambar 6(b), citra rontgen hasil segmentasi pada gambar 6(c) dan hasil citra rontgen setelah dilakukan deteksi tepi pada gambar 6(d). Proses pengolahan citra pada citra rontgen dapat dilihat pada Gambar 6 .
Hasil dari diagnosa citra rontgen TBC dapat dilihat pada Tabel 2 berikut:

Tabel 2. Hasil diagnosa citra rontgen TBC

\begin{tabular}{|l|c|}
\hline Jumlah Piksel Putih pada Deteksi Tepi & 8253 \\
\hline Jumlah Piksel Paru pada Segmentasi & 247590 \\
\hline Persentase (JPP/TPP) & $3,33 \%$ \\
\hline Hasil Diagnosa Penyakit & TBC \\
\hline
\end{tabular}

Citra rontgen menunjukkan penyakit TBC, dimana persentase citra rontgen ini bernilai $3,33 \%$ dan berada dalam interval persentase (2,86\% hingga 3,79\%). Dan terbukti benar/sesuai dengan hasil pada simulasi yaitu menunjukkan penyakit TBC. Perhitungannya adalah sebagai berikut:

$$
\begin{aligned}
\text { Citra Rontgen } & =\frac{\text { Jumlah piksel putih pada sobel }}{\text { Jumlah piksel putih setelah disegmentasi }} \\
& =\frac{8253}{247590} \\
& =3,33 \%
\end{aligned}
$$

\subsection{Sampel citra pleuritis}

Sampel citra rontgen yang diinputkan pada gambar 7(a), kemudian citra asli diperbaiki pada gambar 7(b), citra rontgen hasil segmentasi pada gambar 7(c) dan hasil citra rontgen setelah dilakukan deteksi tepi pada gambar 7(d). Proses pengolahan citra pada citra rontgen dapat dilihat pada Gambar 7.

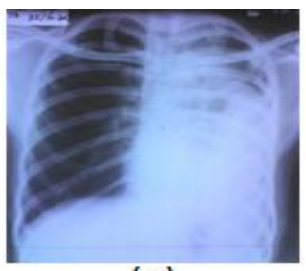

(a)

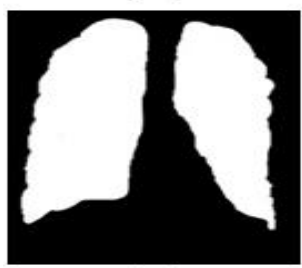

(c)

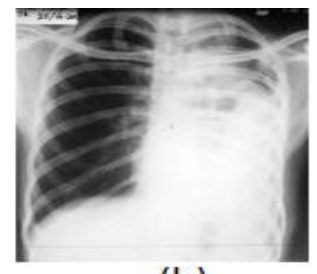

(b)

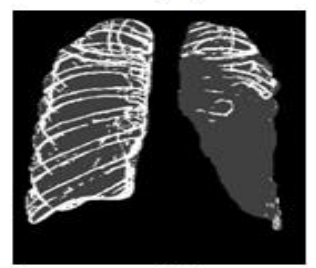

(d)
Gambar 7. Citra Pleuritis (a) citra asli, (b) citra setelah diperbaiki, (c) citra hasil segmentasi (d) citra hasil deteksi tepi 
Hasil dari diagnosa citra rontgen pleuritis dapat dilihat pada Tabel 3 berikut:

Tabel 3. Hasil diagnosa citra rontgen pleuritis

\begin{tabular}{|l|c|}
\hline Jumlah piksel putih pada deteksi tepi & 995 \\
\hline Jumlah piksel paru pada segmentasi & 69650 \\
\hline Persentase (JPP/TPP) & $1,43 \%$ \\
\hline Hasil diagnosa penyakit & Pleuritis \\
\hline
\end{tabular}

Citra rontgen menunjukkan penyakit pleuritis, dimana persentase citra rontgen ini bernilai $1,43 \%$ dan berada dalam interval persentase $(1,43 \%$ hingga $1,59 \%)$. Dan terbukti benar/sesuai dengan hasil pada simulasi yaitu menunjukkan penyakit pleuritis. Perhitungannya adalah sebagai berikut:

$$
\begin{aligned}
\text { Citra Rontgen } & =\frac{\text { Jumlah piksel putih pada sobel }}{\text { Jumiah piksel putih setelah disegmentasi }} \\
& =\frac{995}{69650} \\
& =1,43 \%
\end{aligned}
$$

\section{KESIMPULAN}

Pada pengujian 41 (empat puluh satu) sampel citra rontgen yang diujikan didapatkan hasil kebenaran $100 \%$, dimana nilai ini sesuai dengan sampel uji terhadap interval yang didapatkan.

\section{DAFTAR PUSTAKA}

[1] Saputra, Andri. 2011. Sistem Pakar Identifikasi Penyakit Paru-Paru Pada Manusia Menggunakan Pemrograman Visual Basic 6.0. Jurnal Teknologi Dan Informatika (Teknomatika). Vol. 1 No. 3. STMIK PalComTech Palembang.

[2] Mardhiyah, Ainatul dan Agus Harjoko. 2011. Metode Segmentasi Paru-Paru Dan Jantung Pada Citra Xray Thorax. IJEIS, Vol.1, No.2.

[3] Hidayatno, Achmad, R.Rizal Isnanto dan Bahrun Niam. Analisis Deteksi Tepi pada Citra berdasarkan perbaikan kualitas Citra. Universitas Diponegoro. Semarang.

[4] Ibrahim, Danny, Achmad Hidayatno dan R.Rizal Isnanto. Pengaturan Kecerahan dan Kontras Citra secara Automatis dengan Teknik Pemodelan Histogram. Universitas Diponegoro. Semarang.

[5] Sutoyo, T., dkk. 2009. Teori Pengolahan Citra Digital. Penerbit ANDI Yogyakarta dengan UDINUS Semarang.

[6] Munir, Rinaldi. 2004. Pengolahan Citra Digital dengan Pendekatan Algoritmik, Penerbit Informatika. Bandung.

[7] Astuti, Setia. 2010. Binerisasi Otomatis Pada Citra Bergradasi Dengan Metode Variabel Dan Metode Iterasi. Udinus Semarang Techno.Com, Vol. 9 No. 3.

\section{Biodata Penulis}

Reni Rahmadewi, Lahir di Taluk pada tahun 1983. Menerima gelar sarjana muda di Politeknik Negeri Padang pada tahun 2004 dan menerima gelar sarjana di Fakultas Teknik Universitas Andalas pada tahun 2009. Sekarang tengah menempuh pendidikan jenjang Megister Teknik Elektro Universitas Andalas Padang. 